Jurnal Keperawatan Silampari

Volume 1, Nomor 2, Juni 2018

e-ISSN : 2581-1975

p-ISSN : 2597-7482

DOI: https://doi.org/10.31539/jks.v1i2.83

\title{
HUBUNGAN POLA MAKAN DENGAN KEJADIAN ANEMIA PADA IBU HAMIL DI WILAYAH KERJA PUSKESMAS
}

\author{
Dina Mariana ${ }^{1}$, Dwi Wulandari ${ }^{2}$, Padila $^{3}$ \\ UPTD Puskesmas Jalan Gedang Kota Bengkulu ${ }^{1}$ \\ Program Studi Ners, STIKES Dehasen Bengkulu ${ }^{2}$ \\ Program Studi Ilmu Keperawatan, Universitas Muhammadiyah Bengkulu ${ }^{3}$ \\ dinamarianaskep@gmail.com ${ }^{1}$
}

\begin{abstract}
ABSTRAK
Penelitian ini bertujuan untuk mengetahui hubungan antara pola makan dan kejadian anemia pada ibu hamil di Puskesmas Jalan Gedang Kota Bengkulu. Metode penelitian yang digunakan adalah desain cross sectional analitik deskriptif. Hasil dari 30 responden adalah separuh responden $(50,0 \%)$ memiliki pola makan yang tidak sehat, hampir setengah dari responden $(26,7 \%)$ mengalami anemia. Berdasarkan Chi-Square test $\mathrm{p}$-value $=0,035$. Simpulan dari penelitian ini menunjukkan ada hubungan antara diet dan kejadian anemia pada ibu hamil di Puskesmas Jalan Gedang Kota Bengkulu.
\end{abstract}

Kata Kunci: Anemia, Diet, Ibu Hamil

\section{ABSTRACT}

This study aims to determine the relationship between eating patterns and the incidence of anemia in pregnant women at the Jalan Gedang Health Center in Bengkulu City. The research method used is descriptive analytic cross sectional design. The results of 30 respondents are half of respondents (50.0\%) have unhealthy eating patterns, almost half of respondents (26.7\%) have anemia. Based on the Chi-Square test p-value $=0.035$. The conclusion from this study shows that there is a relationship between diet and anemia in pregnant women at the Puskesmas Jalan Gedang, Bengkulu City.

Keywords: Anemia, Diet, Pregnant Women 


\section{PENDAHULUAN}

Tujuan pembangunan kesehatan nasional salah satunya meningkatkan kemampuan dan kesadaran hidup sehat bagi setiap orang agar terwujud kesehatan masyarakat yang optimal, melalui terciptanya masyarakat bangsa dan negara Indonesia yang ditandai oleh penduduknya yang hidup dengan prilaku sehat dan lingkungan yang sehat, memiliki kemampuan untuk menjangkau pelayanan kesehatan yang bermutu serta dapat diperoleh secara adil dan merata demi terwujudnya derajat kesehatan yang optimal. Untuk mendukung tujuan tersebut maka salah satu tujuan utamanya adalah menurunkan angka kematian ibu dan bayi (Dinas Kesehatan Provinsi Bengkulu, 2015).

Salah satunya indikator keberhasilan pembangunan dalam bidang kesehatan dapat dilihat dari tinggi rendahnya angka kematian ibu dan bayi. Berdasarkan penelitian WHO diseluruh dunia terdapat kematian ibu sebesar 500.000 jiwa pertahun dan kematian bayi khususnya neonatus sebesar 10.000 jiwa per tahun. Kematian maternal dan bayi tersebut terjadi terutama di negara berkembang sebesar $99 \%$. Kematian ibu di Indonesia masih berkisar 425/100.000 persalinan hidup. Sedangkan kematian bayi sekitar 56/10.000 persalinan hidup. Salah satu penyebab kematian pada ibu hamil adalah anemia dalam kehamilan (Manuaba, 2010).

Hasil Riset Kesehatan Dasar (Riskesdas) tahun 2013, prevalensi anemia pada ibu hamil di Indonesia sebesar 37,1\%. Pemberian tablet Fe di Indonesia pada tahun 2015 sebesar $85 \%$. Presentase ini mengalami peningkatan dibandingkan pada tahun 2014 yang sebesar $83,3 \%$. Meskipun pemerintah sudah melakukan program penanggulangan anemia pada ibu hamil yaitu dengan memberikan 90 tablet Fe kepada ibu hamil selama periode kehamilan dengan tujuan menurunkan angka anemia ibu hamil, tetapi kejadian anemia masih tinggi (Kementerian Kesehatan RI, 2013).

Berdasarkan profil Dinas Kesehatan Kota Bengkulu Tahun 2012, angka kejadian ibu hamil dengan anemia sebesar 170 orang dari jumlah 6.856 ibu hamil, tahun 2013 angka kejadian ibu hamil dengan anemia sebesar 168 orang dari jumlah $7.251 \mathrm{ibu}$ hamil, dan tahun 2014 angka kejadian ibu hamil dengan anemia sebesar 279 orang dari jumlah 7.093 ibu hamil. Puskesmas Jalan Gedang merupakan puskesmas yang memiliki jumlah penderita anemia pada ibu hamil terbanyak dibandingkan puskesmas lainnya di wilayah Kota Bengkulu dengan jumlah penderita anemia ibu hamil setiap tahunnya selalu meningkat, tahun 2014 sebesar 60 orang dari 429 orang ibu hamil (Dinkes Kota Bengkulu, 2015).

Anemia merupakan masalah kesehatan masyarakat terbesar di dunia terutama bagi kelompok wanita usia reproduksi (WUS). Menurut WHO secara global prevalensi anemia pada ibu hamil di seluruh dunia adalah sebesar 41,8 \%. Salah satu penyebab anemia pada kehamilan yaitu paritas dan umur ibu. Anemia pada wanita usia subur (WUS) dapat menimbulkan kelelahan, badan lemah, penurunan kapasitas/kemampuan atau produktifitas kerja. Penyebab paling umum dari anemia pada kehamilan adalah kekurangan zat besi, asam folat, dan perdarahan akut dapat terjadi karena interaksi antara keduanya (Noverstiti, 2012).

Anemia juga merupakan salah satu masalah gizi utama di Indonesia. Resiko anemia gizi besi ini dapat menyebabkan produktivitas kerja rendah, daya tahan tubuh terhadap penyakit menurun, kemampuan belajar anak sekolah rendah, peningkatan bobot badan ibu hamil rendah dan kelahiran bayi prematur. Jalan pintas untuk penentuan anemia menggunakan Hb sebagai indikator telah disarankan oleh WHO dan anemia gizi ditetapkan sebagai masalah kesehatan masyarakat Indonesia secara universal. Penyebab anemia tersering adalah defisiensi zat-zat nutrisi. Seringkali 
defisiensinya bersifat multipel dengan manifestasi yang disertai infeksi, gizi buruk atau kelainan herediter. Namun penyebab mendasar anemia nutrisional meliputi asupan yang tidak cukup, absorbsi yang tidak adekuat, bertambahnya zat gizi yang hilang dan kebutuhan yang berlebihan. Sekitar 95\% anemia dalam kehamilan disebabkan oleh defisiensi gizi (Proverawati, 2011).

Anemia pada ibu hamil adalah kondisi ibu dengan kadar hemoglobin dibawah 11 gr \% pada trimester 1 dan 3 atau kadar hemoglobin < 10,5 gr \% pada trimester 2 (Soebroto, 2010). Dampak anemia pada janin antara lain abortus, terjadi kematian intrauterin, prematuritas, berat badan lahir rendah, cacat bawaan dan mudah terkena infeksi. Pada ibu, saat kehamilan dapat mengakibatkan abortus, persalinan prematuritas, ancaman dekompensasi kordis dan ketuban pecah dini. Pada saat persalinan dapat mengakibatkan gangguan his, retensio plasenta dan perdarahan post partum karena atonia uteri (Styawati, 2013).

Pada masa kehamilan zat gizi diperlukan untuk pertumbuhan organ reproduksi ibu maupun untuk pertumbuhan janin. Kebutuhan zat besi ibu selama kehamilan adalah 800 $\mathrm{mg}$ besi diantaranya $300 \mathrm{mg}$ untuk janin plasenta dan $500 \mathrm{mg}$ untuk pertambahan eritrosit ibu, untuk itu ibu hamil membutuhkan 2-3 mg zat besi tiap hari (Manuaba, 2010). Pola makan masyarakat Indonesia pada umumnya mengandung sumber besi hewani yang rendah dan tinggi sumber besi nabati yang merupakan penghambat penyerapan gizi (FKM UI, 2007).

Beberapa faktor yang dapat menyebabkan terjadinya anemia kehamilan diantaranya gravida, umur, paritas, tingkat pendidikan, status ekonomi dan kepatuhan konsumsi tablet Fe dan pola makan (Keisnawati dkk, 2015). Hasil penelitian Ridayanti (2012), menyebutkan bahwa ibu hamil dengan anemia juga disebabkan oleh faktor primigravida. Ibu promigravida yang mengalami anemia kehamilan sebesar $44,6 \%$ sedangkan ibu multigravida yang mengalami anemia kehamilan sebesar 12,8\%. Hal tersebut disebabkan ibu primigravida belum mempunyai pengalaman untuk menjaga kesehatan kehamilan dari kehamilan sebelumnyakarena baru pertama kali hamil (Farsi, 2011).

Pola makan yang baik selama kehamilan dapat membantu tubuh mengatasi permintaan khusus karena hamil, serta memiliki pengaruh positif pada kesehatan bayi. Pola makan sehat pada ibu hamil adalah makanan yang dikonsumsi oleh ibu hamil harus memiliki jumlah kalori dan zat-zat gizi yang sesuai dengan kebutuhan seperti karbohidrat, lemak, protein, vitamin, mineral, serat dan air (Manuaba, 2010). Pola makan ini dipengaruhi oleh beberapa hal yaitu kebiasaan, kesenangan, budaya, agama, taraf ekonomi dan alam. Sehingga faktor-faktor yang mengalami pola makan ibu hamil tersebut berpengaruh pada status gizi ibu.

Pola makan seimbang terdiri dari berbagai makanan dalam jumlah dan proporsi yang sesuai untuk memenuhi kebutuhan gizi seseorang. Pola makan yang tidak seimbang akan menyebabkan ketidakseimbangan zat gizi yang masuk kedalam tubuh dan dapat menyebabkan terjadinya kekurangan gizi atau sebaliknya pola konsumsi yang tidak seimbang juga mengakibatkan zat gizi tertentu berlebih dan menyebabkan terjadinya gizi lebih (Waryana, 2010). Kekurangan asupan gizi pada ibu hamil selama kehamilan selain berdampak pada berat bayi lahir juga akan berdampak pada ibu hamil yaitu akan menyebabkan anemia pada ibu hamil (Zulaikha, 2015).

Ibu hamil juga dianjurkan untuk mengonsumsi beragam makanan yang diolah dari empat jenis pokok makanan, yaitu: beras atau alternatif penggantinya, buah-buahan, 
sayur-mayur, dan daging atau alternatif penggantinya. Makanan yang dikonsumsi setiap harinya haruslah terdiri dari empat macam panganan ini. Hal ini disebabkan karena masing-masing golongan makanan ini mengandung nutrisi yang berbeda-beda, contohnya: daging serta alternatif penggantinya mengandung protein, namun tidak mengandung vitamin $\mathrm{C}$ yang sangat dibutuhkan oleh tubuh. Dengan jeli memilih variasi makanan yang dibutuhkan maka kita dapat memastikan jika makanan yang kita konsumsi mengandung nutrisi yang seimbang (Keisnawati dkk, 2015). Jika pola makan seimbang ini tidak terpenuhi, maka cenderung mengakibatkan anemia saat kehamilannya.

Anemia kehamilan disebut potential danger to mother and child (potensial membahayakan ibu dan anak). Dampak dari anemia pada kehamilan dapat terjadi abortus, persalinan pre-maturitas, hambatan tumbuh kembang janin dalam rahim, mudah terjadi infeksi, perdarahan antepartum, ketuban pecah dini (KPD), saat persalinan dapat mengakibatkan gangguan His, kala pertama dapat berlangsung lama, dan terjadi partus terlantar, dan pada kala nifas terjadi subinvolusi uteri menimbulkan perdarahan pospartum, memudahkan infeksi puerperium, dan pengeluarkan AS1 berkurang (Aryanti dkk, 2013).

Menurut data Puskesmas Jalan Gedang kejadian anemia pada ibu hamil tahun 2017 berjumlah 64 orang dari 302 orang ibu hamil TM I, II dan TM III. Berdasarkan survey awal di wilayah kerja Puskesmas Jalan Gedang Kota Bengkulu tanggal 15 februari Tahun 2017 terhadap ibu hamil yang berkunjung ke Puskesmas Jalan Gedang sebanyak 5 orang, 2 orang dikatakan petugas kesehatan $\mathrm{Hb}<11 \mathrm{gr} / \mathrm{dl}$. Setelah penulis konfirmasi 5 orang ibu hamil mengatakan pola makannya tidak teratur dan menu makanan yang disajikan pun seadanya, hal ini karena keadaan ekonomi yang kurang memadai sedangkan harga keperluan semua mahal dan tablet Fe pun dikonsumsi tidak teratur karena membuat ibu mual sehingga kebutuhan zat besi tidak tercukupi. Dan ibu hamil memeriksakan kehamilanya hanya karena ada keluhan saja seperti pusing, mual, bukan berdasarkan jadwal ANC.

Beberapa hasil penelitian pada masyarakat khususnya masyarakat pesisir anemia dianggap wajar yang ditandai dengan keadaan pucat dengan gejala pusing, lemah/kurang bergairah. Penyebab anemia menurut mereka karena ibu hamil kerja berat dan malas makan. Dianggap sesuatu hal yang wajar sebagai konsekuensi dari setiap kehamilan dan berusaha diatasi sendiri berdasarkan pengalaman dari generasi sebelumnya yaitu cukup dengan mengurut-urut kepala ibu sambil banyak beristirahat. Ibu hamil dalam menginterpretasikan masalah kesehatannya sendiri di dasarkan atas gejala atau rasa sakit yang mereka alami. Ada ibu hamil yang beranggapan jika gangguan kesehatan selama hamil adalah suatu hal yang wajar, ada juga yang mengalami gejala atau rasa sakit selama hamil jika masih dalam taraf ringan mereka berusaha mengatasi sendiri. Jika usaha tersebut ternyata tidak berhasil, baru kemudian mencari pertolongan pelayanan kesehatan tradisional atau pun professional (Manoe, 2010). 


\section{METODE PENELITIAN}

Desain penelitian ini menggunakan survey analitik dengan rancangan crosssectional dimana pengukuran atau pengamatan variabel independen (pola makan pada ibu hamil) dan variabel dependen (kejadian anemia) dilakukan dalam waktu bersamaan dan hasilnya hanya menggambarkan situasi dan kondisi pada saat penelitian dilakukan (Alimul, 2010).

Teknik pengumpulan data yang digunakan dalam penelitian ini adalah dengan menggunakan data primer dan data sekunder. Data primer adalah data yang diperoleh peneliti secara langsung (dari tangan pertama), sementara data sekunder adalah data yang diperoleh peneliti dari sumber yang sudah ada (Alimul, 2010). Pengumpulan data diambil dengan cara menyebarkan kuisioner yang berisi 20 pertanyaan kepada 30 orang ibu hamil, dan hasil cek HB yang dilihat dari status pasien di Puskesmas Jalan Gedang Kota Bengkulu pada akhir pemeriksaan ibu hamil. Analisa data menggunakan analisa data univariat dan bivariat. Analisa dilakukan dengan tabulasi silang dan uji statistik dengan menggunakan rumus Chi Square dengan derajat kepercayaan $95 \%$ bila p value < 0,05 menunjukkan hubungan bermakna dan tidak bermakna jika $\mathrm{p}$ value $>0,05$.

\section{HASIL PENELITIAN}

Puskesmas Jalan Gedang terdiri dari Puskesmas Induk dan Pustu L.Butai, K.Tebeng, dan SL.Baru. Program yang dilaksanakan di Puskesmas jalan gedang, terdapat enam program yaitu Kesehatan Ibu dan Anak (KIA), Keluarga Berencana (KB), Kesehatan Lingkungan, Pemberantasan Penyakit Menular (P2M), promosi kesehatan, dan perbaikan gizi (Profil Puskesmas jalan gedang, 2017).

Fasilitas yang terdapat di Puskesmas Jalan Gedang Kota Bengkulu diantaranya 1 buah gedung Puskesmas, 3 buah gedung puskesmas pembantu, 1 buah kendaraan roda empat, 6 buah kendaraan roda dua dengan kondisi 3 sangat baik dan 3 rusak ringan, timbangan berat badan, pengukuran tinggi badan, body feat, Tensi meter, Brangkar, Mikroskop, dan pemeriksaan mounth dental chair (Profil Puskesmas jalan gedang, 2017).

Tabel. 1

Distribusi Frekuensi Pola Makan Ibu Hamil

\begin{tabular}{lcc}
\hline \multicolumn{1}{c}{ Pola Makan } & Frekuensi & Persentase $(\%)$ \\
\hline Tidak Sehat & 15 & 50,0 \\
Sehat & 15 & 50,0 \\
\hline Total & 30 & 100,0 \\
\hline
\end{tabular}

Berdasarkan hasil tabel 1 di atas dapat diketahui bahwa dari 30 responden yang dijadikan sampel, terdapat sebagian responden $(50,0 \%)$ memiliki pola makan yang tidak sehat.

Tabel. 2

Distribusi Frekuensi Kejadian Anemia pada Ibu Hamil

\begin{tabular}{lcc}
\hline \multicolumn{1}{c}{ Kejadian Anemia } & Frekuensi & Persentase $(\%)$ \\
\hline Anemia & 8 & 26,7 \\
Tidak Anemia & 22 & 73,3 \\
\hline Total & 30 & 100,0 \\
\hline
\end{tabular}


Berdasarkan hasil tabel 2 di atas dapat diketahui bahwa dari 30 responden yang dijadikan sampel, terdapat hampir sebagian kecil responden $(26,7 \%)$ mengalami anemia.

Tabel. 3

Hubungan Pola Makan dengan Kejadian Anemia

\begin{tabular}{lccccccc}
\hline \multirow{3}{*}{ Pola Makan } & \multicolumn{6}{c}{ Kejadian Anemia } & \multirow{2}{*}{ P-value } \\
\cline { 2 - 7 } & \multicolumn{2}{c}{ Anemia } & \multicolumn{2}{c}{ Tidak Anemia } & \multicolumn{2}{c}{ Total } & P-val \\
\cline { 2 - 7 } & $\mathrm{N}$ & $\%$ & $\mathrm{n}$ & 8 & $\mathrm{n}$ & $\%$ & \\
\hline Tidak Sehat & 7 & 46,7 & 63,3 & 15 & 100,0 & 0,035 \\
Sehat & 1 & 6,7 & 14 & 93,3 & 15 & 100,0 & \\
& & & & & & &
\end{tabular}

Berdasarkan hasil tabel 3 diatas menunjukkan bahwa dari 15 responden yang pola makan tidak sehat terdapat hampir sebagian besar responden $(46,7 \%)$ mengalami anemia, sedangkan dari 15 responden yang pola makan sehat terdapat hampir seluruh responden $(93,3 \%)$ tidak mengalami anemia. Hasil analisis bivariat menggunakan uji statistik Chi-square (Fisher's Exact Test) didapat nilai $p$-value $=0,035<\alpha 0,05$ berarti signifikan maka Ho ditolak dan Ha diterima, yang menunjukan ada hubungan antara pola makan dengan kejadian anemia pada ibu hamil.

\section{PEMBAHASAN}

\section{Gambaran Pola Makan Ibu Hamil}

Berdasarkan hasil tabel 1 di atas dapat diketahui bahwa dari 30 responden yang dijadikan sampel, terdapat sebagian responden $(50,0 \%)$ memiliki pola makan yang tidak sehat.

Hal ini menunjukkan bahwa pola makan yang kurang baik saat kehamilan akan menyebabkan asupan protein dan vitamin tidak sesuai dengan kebutuhan, metabolisme tidak seimbang sehingga pembentukan $\mathrm{Hb}$ terhambat dan kebutuhan tubuh akan zat gizi baik mikro maupun makro tidak terpenuhi, sehingga akan berakibat pada munculnya berbagai masalah gizi dan anemia baik ringan, sedang maupun berat saat kehamilan (Soetjiningsih, 2007).

Sejalan dengan teori menurut Nadeak (2011) pola makan adalah cara seseorang, kelompok orang dan keluarga dalam memilih jenis dan jumlah bahan makanan yang dimakan setiap hari oleh satu orang atau lebih dan mempunyai khas untuk satu kelompok tertentu. Penanaman pola makan yang beraneka ragam makanan harus dilakukan sejak bayi, saat bayi masih makan nasi tim, yaitu ketika usia baru enam bulan ke atas, ibu harus tahu dan mampu menerapkan pola makan sehat. Selama masa hamil atau menyusui ibu harus memperhatikan makanan yang dikonsumsi. Makanan bergizi adalah makanan yang mengandung zat tenaga, zat pembangun, dan zat yang sesuai dengan kebutuhan gizi. Makanan bergizi ini untuk memenuhi kebutuhan janin dan meningkatkan produksi ASI (Soetjiningsih, 2012).

Kehamilan adalah suatu anugerah terindah yang diberikan oleh Tuhan kepada setiap perempuan di dunia. Menjaga pola hidup sehat dan makanan bergizi adalah salah satu cara untuk menjaga anugerah dari Tuhan. Pola makanan sehat dengan menu seimbang sangat penting untuk perkembangan janin dalam kandungan. Tetapi kadang kala calon ibu kurang memperhatikan hal tersebut. Padahal dengan cara itulah janin dalam kandungan menjadi sehat sampai dengan bayi itu dilahirkan. Wanita sebagai 
calon ibu harus di dorong makan makanan yang banyak mengandung gizi. Karena pada saat masa kehamilan kebutuhan akan kalsium, zat besi, dan asam folat meningkat (Manuaba, 2010).

Pola makan ibu selama masa kehamilannya membutuhkan tambahan-tambahan zat besi dan tambahan multivitamin, kebutuhannya akan zat besi hampir dua kali lipat. Untuk mendapatkan lebih banyak manfaat zat besi ibu harus banyak konsumsi sayuran, seperti buncis, artichoke, dan kacang merah, serta mengkombinasikan dengan makananmakanan yang mengandung vitamin $\mathrm{C}$, seperti buah-buahan sitrusg, brokoli, paprika, maupun stroberi. Hal ini disebabkan zat besi yang berasal dari tumbuhan tidak diserap seefektif kandungan zat besi dari daging merah, ikan, dan daging unggas. Sehingga ibu membutuhkan vitamin C yang berfungsi menyerap mineral ini (Sulistyoningsih, 2011).

Berdasarkan teori yang dikemukakan Manuaba (2010) pada kehamilan trimester III janin mengalami pertumbuhan dan perkembangan yang sangat pesat serta bahan makanan sumber zat pembangun dan pengatur perlu diberikan lebih banyak dibandingkan pada trimester II karena selain untuk pertumbuhan janin yang sangat pesat, juga diperlukan ibu dalam persiapan persalinan. Dan walaupun nampaknya janin mampu menyerap berbagai nutrisi dari ibunya, dengan adanya anemia kemampuan metabolisme tubuh akan berkurang sehingga pertumbuhan dan perkembangan janin dalam rahim akan terganggu Sumber besi adalah makanan hewani, seperti daging, ayam, dan ikan. Sumber baik lainnya adalah telur, serealia tumbuk, kacang-kacangan, sayuran hijau dan beberapa jenis buah. Disamping jumlah besi, perlu diperhatikan kualitas besi di dalam makanan. Pada umumnya besi didalam daging, ayam dan ikan mempunyai ketersediaan biologic sedang, dan besi di dalam sebagian besar sayuran, terutama yang mengandung asam oksalat tinggi, seperti bayam mempunyai ketersediaan biologik rendah. Sebaiknya diperhatikan kombinasi makanan sehari-hari, yang terdiri atas campuran sumber besi berasal dari hewan tumbuh-tumbuhan serta sumber gizi lain yang dapat membantu obsorpsi.

Hal ini dijelaskan oleh Arisman (2010) bahwa ibu hamil membutuhkan keseimbangan antara protein dan lemak yang tertimbun dalam tubuh untuk pertumbuhan ibu dan janin. Kebutuhan energi pada trimester III sebesar $350 \mathrm{kkal}$, apabila dalam masa kehamilan seorang ibu tidak bisa memenuhi kebutuhan energinya selama hamil, maka tidak dapat mencapai berat badan yang optimal. 5 responden $(10,1 \%)$ menjawab kurang setuju pada pernyataan no 6 yaitu ibu hamil perlu mengkonsumsi makanan yang mengandung karbohidrat. bahan makanan yang menjadi sumber karbohidrat berasal dari sereal, padi-padian, kentang, dan roti gandum.

Pemenuhan karbohidrat harus seimbangnya kepada energi tidak kurang atau lebih. Asupan karbohidrat yang tidak mencukupi akan mengakibatkan tidak cukupnya glukosa yang tersedia untuk menghasilkan energi. Protein hewani dapat meningkatkan penyerapan zat besi dalam tubuh. protein merupakan salah satu zat gizi yang dibutuhkan untuk penyerapan zat besi. Dengan rendahnya konsumsi protein maka dapat menyebabkan rendahnya penyerapan zat besi oleh tubuh. Keadaan ini dapat mengakibatkan tubuh kekurangan zat besi dan dapat menyebabkan anemia atau penurunan kadar $\mathrm{Hb}$. Asam organik, seperti vitamin $\mathrm{C}$ sangat membantu penyerapan besi-nonhem dengan merubah bentuk feri menjadi fero. Bentuk fero lebih mudah diserap. Vitamin $\mathrm{C}$ di samping itu membentuk gugus besi-askorbat yang tetap larut pada $\mathrm{pH}$ lebih tinggi dalam duodenum. Oleh karena itu, sangat dianjurkan memakan makanan sumber vitamin C tiap kali makan. Asam organi lain adalah asam sitrat. Asam folat dikenal sebagai tambahan atau suplementasi dalam susu. Namun sebenarnya asam 
folat sendiri secara alami terkandung dalam makanan sehari-hari kita, seperti sayuran hijau, hati, daging, kacang, biji dan sebagainya. Dan menurut tabel nutrisi makanan Indonesia, kandungan asam folat yang tinggi terkandung dalam hati ayam, rumput laut, kacang merah dan kacang kedelai (Arisman, 2010).

Vitamin A berperan dalam memobilisasi cadangan besi di dalam tubuh untuk dapat mensintesa hemoglobin. Status vitamin A yang buruk berhubungan dengan perubahan metabolisme besi pada kasus kekurangan besi. Vitamin A terdapat khusus di dalam bahan makanan hewani seperti hati sapi, ayam, serta telur, sedangkan bahan makanan nabati hanya mengandung provitamin A, yang disebut karoten terdapat di wortel, bayam, kangkung, ubi rambat merah, jagung dan kacang hijau. Pola makan pada ibu hamil harus terpenuhi yang mencakup zat gizi makro (karbohidrat, lemak, dan protein) dan zat gizi mikro (vitamin dan mineral). hal ini menunjukan sebagian sudah terwakili pada kuesioner pola makan. Hasil penelitian ini sesuai dengan penelitian yang dilakukan oleh Zulaikha (2015) yaitu sebagian besar mayoritas ibu hamil Trimester III yang memiliki pola makan cukup sebanyak 15 orang (50,0\%) (Manuaba, 2010).

\section{Gambaran Anemia Ibu Hamil}

Berdasarkan hasil tabel 2 di atas dapat diketahui bahwa dari 30 responden yang dijadikan sampel, terdapat hampir sebagian responden $(26,7 \%)$ mengalami anemia. Anemia adalah keadaan menurunya kadar hemoglobin, hematokrit dan jumlah sel darah merah dibawah nilai normal yang dipatok untuk perorangan. Penyebab anemia ini dapat terjadi karena: 1) kehilangan darah secara kronis seperti penyakit ulkus peptikum, hemoroid, infestasi parasit dan proses keganasan, 2) asupan zat besi tidak cukup dan penyerapan tidak adekuat, 3) peningkatan kebutuhan akan zat besi untuk pembentukan sel darah merah yang lazim berlangsung pada masa pertumbuhan bayi, masa pubertas, masa kehamilan, dan menyusui serta pola makan yang tidak seimbang.

Saifudin (2009) menjelaskan penyebab terjadinya anemia yaitu selama kehamilan terjadi peningkatan volume darah (hypervolemia). Hypervolemia merupakan hasil dari peningkatan volume plasma dan eritrosit (sel darah merah) yang beredar dalam tubuh.Tetapi peningkatan ini tidak seimbang yaitu volume plasma peningkatannya jauh lebih besar sehingga memberikan efek yaitu konsentrasi hemoglobin berkurang dari 12 $\mathrm{mg} / 10 \mathrm{mg}$.

Manuaba (2010) menjelaskan bahwa anemia dalam kehamilan dapat mengakibatkan terjadinya abortus, persalinan premature, hambatan tumbuh kembang janin dalam rahim, mudah terjadi infeksi, mola hidatosa, hyperemesis gravidarum, perdarahan antepartum, dan ketuban pecah dini (KPD). Untuk mencegah hal tersebut ibu hamil perlu meningkatkan konsumsi makanan yang bergizi yaitu makan makanan yang banyak mengandung zat besi dari bahan makanan hewani (daging, ikan, ayam, telur, hati) dan bahan makanan nabati (sayuran berwarna hijau tua, kacang-kacangan), makan sayur-sayuran dan buah-buahan yang banyak mengandung vitamin $\mathrm{C}$ (bayam, jambu, tomat, jeruk), menambah pemasukan zat besi kedalam tubuh dengan minum tablet tambah darah (Almatzier, 2009).

Hasil penelitian ini sesuai dengan penelitian Salmariantity (2012) yang menunjukkan hubungan antara umur dan pola makan dengan kejadian anemia pada ibu hamil dengan nilai uji statistik terbukti signifikan $\mathrm{p}$ value $=0,012<0,005$ dengan nilai Prevalance Ratio (PR) $=1,8$ dan 95\% CI antara 1,07 -3,28 yang artinya ibu hamil pada umur beresiko (<20 Tahun) berpeluang mendapatkan anemia 1,8 kali dibandingkan dengan ibu hamil pada umur tidak beresiko (20-35 Tahun). 


\section{Hubungan Pola Makan dengan Anemia Ibu Hamil}

Berdasarkan hasil penelitian tabel 1 diketahui bahwa dari 30 responden yang dijadikan sampel, terdapat setengah responden $(50,0 \%)$ ibu hamil memiliki pola makan yang tidak sehat, hal ini terlihat dari jawaban kuesioner yang disebarkan nilai rata-rata jawaban benar < 15 jawaban yang kurang dari nilai median dilihat dari segi pengaturan jumlah dan jenis makanan yang belum sesuai dengan gizi seimbang ibu hamil, ibu tidak sarapan pagi, makanan seadanya, makan terlalu sedikit, makan yang mengandung protein hanya sedikit tidak sesuai kebutuhan gizi seimbang, terlalu banyak gula dan minyak, tidak pernah makan makanan cemilan, dan terlalu sering mengkonsumsi makanan yang cepat saji. Selain dari hasil jawaban kuesioner ada faktor lain yang mempengaruhi pola makan ibu hamil tidak sehat diantaranya tingkat pendidikan sehingga pengetahuan ibu kurang akan pola makan sehat bagi ibu hamil, status ekonomi yang tidak mampu untuk memenuhi kebutuhan, ibu mengalami mual muntah yang menyebabkan ibu tidak mau makan, dan lingkungan.

Penelitian ini sejalan dengan penelitian yang dilakukan oleh Chairil (2017) yang menyatakan bahwa terdapat hubungan antara pola makan dengan kejadian anemia pada ibu hamil Trimeter III di Puskesmas Jetis Kota Yogyakarta. Penelitian yang dilakukan oleh Zulaikha (2015) menyatakan bahwa pola makan mempunyai hubungan yang signifikan terhadap kejadian anemia pada ibu hamil trimester III yang diteliti di Puskesmas Pleret Bantul Yogyakarta.

Hasil penelitian ini sesuai dengan pendapat Amirudin (2007) bahwa penyebab kejadian anemia dapat disebabkan oleh asupan zat besi yang tidak cukup dan penyerapan tidak adekuat serta peningkatan kebutuhan akan zat besi untuk pembentukan sel darah merah, masa pubertas, masa kehamilan dan menyusui serta pola makan yang tidak seimbang. Dengan pola makan yang tidak seimbang yaitu tidak memenuhi persyaratan pola makan empat sehat lima sempurna, maka ibu dan bayi akan mengalami kekurangan zat-zat yang dibutuhkan terutama zat besi yang lebih besar untuk pembentukan sel darah merah yang sangat berguna bagi partum buhan bayi. Dengan pola makan yang tidak seimbang, zat besi tersebut tidak akan dapat terpenuhi sehingga ibu hamil akan mengalami kejadian anemia.

Anemia merupakan salah satu masalah kesehatan diseluruh dunia terutama negara berkembang. Sebagian besar anemia pada kehamilan disebabkan oleh defisiensi besi dan perdarahan akut, bahkan tidak jarang keduanya saling berinteraksi. Anemia merupakan salah satu faktor risiko penyebab kematian ibu. Angka kematian ibu hamil akibat anemia di Indonesia adalah $70 \%$ atau 7 dari 10 ibu hamil. Tingginya anemia pada bumil dapat mencerminkan ketidakmampuan sosial ekonomi keluarga atau seluruh komponen bangsa karena nilai gizi tidak memenuhi syarat kesehatan (Manuaba, 2015). Anemia dalam kehamilan dapat mengakibatkan dampak yang membahayakan bagi ibu dan janin. Anemia pada ibu hamil dapat meningkatkan risiko terjadinya pendarahan post partum. Bila anemia terjadi sejak awal kehamilan dapat menyebabkan terjadinya persalinan prematur (Proverawati, Asfuah, 2013).

Penyebab paling umum dari anemia pada kehamilan adalah kekurangan zat besi. Hal ini penting dilakukan pemeriksaan anemia pada kunjungan pertama kehamilan. Bahkan jika tidak mengalami anemia pada saat kunjungan pertama, masih mungkin terjadi anemia pada kehamilan lanjutannya. Ibu hamil memerlukan banyak zat gizi untuk memenuhi kebutuhan tubuh pada diri dan janinnya. Kekurangan zat besi mengakibatkan kekurangan hemoglobin $(\mathrm{Hb})$, dimana zat besi sebagai salah satu unsur 
pembentuknya. Hemoglobin berfungsi sebagai pangkat oksigen yang sangat dibutuhkan untuk metabolisme sel (Sulistyawati, 2011).

Faktor-faktor yang mempengaruhi terjadinya anemia dalam kehamilan yaitu faktor langsung, tidak langsung dan faktor dasar. Faktor langsung terdiri dari kepatuhan mengkonsumsi zat besi, penyakit infeksi, perdarahan. Faktor tidak langsung terdiri dari kunjungan Antenatal Care (ANC), sikap, paritas, jarak kehamilan, umur, pola makan. Faktor dasar terdiri dari sosial ekonomi, pengetahuan, pendidikan, budaya (Istiarti, 2012).

Pola makan sehat adalah suatu cara atau usaha dalam pengaturan jumlah dan jenis makanan dengan informasi gambaran dengan meliputi mempertahankan kesehatan, status nutrisi, mencegah atau membantu kesembuhan penyakit (Depkes RI, 2009). Kehamilan adalah akibat proses pembuahan yang terjadi selama $12-24$ jam dari waktu dimulainya sel telur dilepaskan. Sperma dapat bertahan kurang lebih selama 5 hari. Jika sperma berhasil membuahi telur, telur akan menuju ke uterus dan menempel di lapisan tebal yang terdapat di dalamnya. Setelah itu, tubuh mulai memproduksi hormon kehamilan. Dikehamilannya seorang ibu banyak membutuhkan energi yang dihasilkan dari sumber makanan yang harus di konsumsi dengan mengikuti pola makan yang sehat.

Pola makan sehat pada ibu hamil adalah makanan yang dikonsumsi oleh ibu hamil harus memiliki jumlah kalori dan zat-zat gizi yang sesuai dengan kebutuhan. Ibu hamil yang pola makannya sehat bisa mengalami anemia, hal ini bisa terjadi karena banyak faktor yang mempengaruhi bukan hanya pola makannya tetapi ada yang mempengaruhi yaitu tidak mengkonsumsi tablet fe atau sejenis asam folat, tidak mengkonsumsi susu kehamilan, hamil pada usia beresiko, kegagalan untuk menyerap zat besi karena minum tea atau kopi, terjadi perdarahan selama kehamilan, janin kembar, pemakaian antasida dapat mengurangi penyerapan zat besi yang dikeluarkan melalui saluran pencernaan menjadi lebih banyak, dan penyakit kronik (Manuaba, 2010). Selain pola makan ada beberapa hal yang mempengaruhi ketersedian zat besi dalam bahan makan salah satunya yaitu cara pengolahan bahan pangan. Cara pengolahan bahan makan dapat mempengaruhi bioavabilitas zat besi dalam bahan makanan, cara pencucian misalnya dapat melarutkan zat besi dalam air. Selain itu proses pemanasan bahan makanan juga dapat mempengaruhi kandungan zat besi didalam bahan makanan.

Pola makan yang baik selama kehamilan dapat membantu tubuh mengatasi permintaan khusus karena hamil, serta memiliki pengaruh positif pada kesehatan bayi. Polamakan sehat pada ibu hamil adalah makanan yang dikonsumsi oleh ibu hamil harus memiliki jumlah kalori dan zat-zat gizi yang sesuai dengan kebutuhan seperti karbohidrat, lemak, protein, vitamin, mineral, serat dan air (Manuaba,2015). Pola makan ini dipengaruhi oleh beberapa hal yaitu kebiasaan, kesenangan, budaya, agama, taraf ekonomi dan alam. Sehingga faktor-faktor yang mengalami pola makan ibu hamil tersebut berpengaruh pada status gizi ibu. Jika pola makan seimbang ini tidak terpenuhi, maka cenderung mengakibatkan anemia saat kehamilannya (Keisnawati dkk, 2015).

Sedangkan ibu hamil yang pola makannya tidak sehat, tidak mengalami anemia hal ini bisa terjadi karena ibu hamil untuk memenuhi kebutuhan zat besi digantikannya dengan mengkonsumsi tablet fe secara teratur dan minum susu kehamilan, sering makan cemilan yang sehat seperti bubur kacang hijau, hamil pada usia yang tidak beresiko, selama kehamilan tidak terjadi perdarahan, tidak mengkonsumsi kopi, dan tidak mempunyai penyakit kronik. 
Hasil uji statistik menunjukan ada hubungan yang bermakna antara pola makan dengan kejadian anemia pada ibu hamil, dengan nilai $p$-value $=0,019<\alpha 0,05$. Responden yang pola makan tidak sehat akan lebih beresiko mengalami anemia daripada orang yang pola makan sehat. Hal ini karena salah satu penyebab anemia adalah defisiensi zat besi karena pola makan tidak sehat dan pengaturan jumlah dan jenis yang tidak sesuai dengan gizi seimbang ibu hamil.

Hasil penelitian didukung teori Rustam Mocthar (2006) yang mengatakan salah satu faktor yang mempengaruhi ibu hamil mengalami anemia adalah karena pola makan tidak sehat. Sebuah pola makan yang cukup selama kehamilan dapat membantu tubuh mengatasi permintaan khusus karena hamil, serta memiliki pengaruh positif pada kesehatan janin. Menurut Krisnatuti, D. (2008) makanan yang dikonsumsi ibu hamil harus meliputi 6 kelompok yaitu makanan yang mengandung karbohidrat, lemak, protein, vitamin, mineral dan air. Apabila masukan gizi pada ibu hamil tidak sesuai dengan kebutuhan maka kemungkinan akan terjadi gangguan dalam kehamilan salah satunya adalah anemia.

Pendapat Rustam, M. (2006) di atas sesuai dengan hasil penelitian di wilayah kerja Puskesmas Jalan Gedang setengah responden dengan pola makan yang tidak sehat dapat mengakibatkan tidak terpenuhinya kebutuhan gizi seimbang ibu hamil. Makanan sehari-hari untuk ibu hamil harus terpenuhi secara kuantitas maupun kualitasnya serta jadwal makan yang teratur guna memenuhi kebutuhan zat gizi yang digunakan untuk fungsi normal tubuh, sebaliknya jika makanan yang dikonsumsi tidak terpenuhi secara kuantitas maupun kualitasnya serta jadwal makan yang tidak teratur maka tubuh akan mengalami kekurangan zat-zat gizi tertentu yang salah satu akibatnya adalah anemia pada ibu hamil. Ibu hamil juga dianjurkan mengkonsumsi tablet Fe secara teratur untuk mencegah terjadinya anemia. Hal ini dibuktikan dengan hasil tabulasi silang yang dijelaskan pada tabel 3 bahwa terdapat hubungan antara pola makan dengan kejadian anemia di wilayah kerja Puskesmas Jalan Gedang Kota Bengkulu.

Hasil penelitian sejalan dengan penelitian Suranto (2013) dengan judul hubungan antara pola makan dengan terjadinya anemia pada ibu hamil di Puskesmas Dawe Kecamatan Dawe Kabupaten Kudus, dengan hasil penelitian sebagian besar ibu hamil memiliki kuantitas makanan dalam kategori kurang sebanyak (46,9\%), sebagian besar ibu jenis makanan kurang (50\%), sebagian besar cara memasak makanan ibu hamil dalam kategori kurang (46,9\%), dan ada hubungan kuantitas, jenis makanan dan cara memasak makanan dengan terjadinya anemia pada ibu hamil di Puskesmas Dawe Kecamatan Dawe Kabupaten Kudus.

Dan didukung juga penelitian Pertiwi (2013) dengan judul hubungan antara pola makan dengan kejadian anemia pada ibu hamil di Wilayah Kerja Puskesmas Kerjo Kabupaten Karanganyar, dengan hasil penelitian $49 \%$ ibu hamil memiliki kebiasaan makan utama $<3$ kali sehari, 16,3\% ibu hamil mengkonsumsi kurang dari 5 jenis makanan sehari, 36,7 ibu hamil mengalami anemia dan 63,3\% tidak anemia, ada hubungan antara frekuensi makan denga kejadian anemia $(\mathrm{p}=0,002)$, ada hubungan antara jenis makanan dengan kejadian anemia $(\mathrm{p}=0,01)$, dan disimpulkan hasil penelitian terdapat hubungan pola makan dengan kejadian anemia pada ibu hamil.

Hasil penelitian ini sejalan dengan penelitian Sandrayayuk dkk, (2013) dengan judul hubungan pola makan dengan kejadian anemia pada ibu hamil trimester III di Puskesmas Pleret Bantul, dengan hasil ada hubungan pola makan dengan kejadian anemia pada ibu hamil trimester III di Puskesmas Pleret Bantul. Dengan 43,3\% ibu hamil pola makan baik, $50 \%$ ibu hamil pola makan sedang, $6,7 \%$ ibu hamil pola makan 
kurang, 43,3\% ibu hamil tidak anemia, 53,3\% ibu hamil anemia ringan, 3,3\% ibu hamil anemia sedang.

Pola makan pada responden yang kurang baik yaitu kebutuhan zat gizi makro (karbohidrat, lemak, dan protein) ataupun mikro (vitamin dan mineral). tidak terpenuhi sehingga berakibat pada munculnya berbagai masalah gizi dan anemia. Kejadian anemia pada ibu hamil tidak hanya disebabkan oleh pola makan yang kurang baik, hal ini dibuktikan dengan hasil penelitian yang menunjukan terdapat responden yang memiliki pola makan cukup tetapi mengalami kejadian anemia sebanyak 12 orang $(24,4 \%)$. Hal ini menunjukan tidak hanya pola makan yang mempengaruhi terjadinya anemia tetapi faktor lain seperti kurangnya kandungan vitamin B12, protein, dan Asam Folat dalam makanan yang dikonsumsi serta kekurangan kalsium yang diperlukan untuk pertumbuhan tulang dan gigi. Saat hamil, kalsium di dalam tubuh ibu akan diserap oleh janin, terutama bila ia tidak mendapatkannya dari makanan. Sehingga ibu hamil harus memilih susu berkalsium tinggi yang non-fat atau low-fat. Yoghurt, keju, butter, dan es krim juga bisa jadi sumber kalsium yang baik yang dapat memenuhi kebutuhan ibu selama kehamilannya.

Hal ini sejalan dengan teori Tarwoto, Wasnindar (2010) yang menyatakan salah satu klasifikasi anemia yaitu anemia megaloblastik. Anemia megaloblastik adalah anemia yang disebabkan kekurangan vitamin B12, Asam Folat dan gangguan sintesis DNA. Jenis makanan yang mengandung vitamin B12 dan Asam Folat berupa kacangkacangan, buah-buahan dan sayuran.

\section{SIMPULAN}

Dari hasil penelitian yang telah dilakukan dapat disimpulkan sebagai berikut :

Sebagian besar responden ibu hamil di Wilayah Kerja Puskesmas Jalan Gedang Kota Bengkulu mempunyai pola makan tidak sehat. Sebagian kecil responden ibu hamil di Wilayah Kerja Puskesmas Jalan Gedang Kota Bengkulu mengalami anemia. Ada hubungan antara pola makan dengan kejadian anemia pada ibu hamil di Wilayah Kerja Puskesmas Jalan Gedang Kota Bengkulu Tahun 2017.

\section{SARAN}

1. Akademik. Diharapkan hasil penelitian ini dapat menjadi referensi bagi mahasiswa keperawatan dalam proses pembelajaran dikelas dan menjadi bekal penyuluhan kesehatan ketika anak praktik dilapangan dan kepada pihak akademik juga diharapkan dapat menyediakan serta melangkapi buku-buku tentang pola makan yang sehat pada ibu hamil, sehingga dapat menjadi bahan referensi bagi mahasiswa.

2. Bagi peneliti selanjutnya. Diharapkan agar dapat menyempurnakan penelitian ini dengan menambah variabel lain dan dengan menambahkan faktor-faktor lainnya yang dapat menyebabkan anemia seperti faktor paritas dan usia ibu hamil ataupun meneliti variabel lainnya yang lebih bervariasi dan mencakup penelitian yang lebih luas dengan metode penelitian yang berbeda terutama yang berhubungan dengan kejadian anemia pada ibu hamil sehingga penelitian dapat terus di kembangkan.

3. Puskesmas. Diharapkan petugas KIA dan gizi agar dapat meningkatkan penyuluhan, konseling kesehatan pada ibu hamil dan pasangan usia subur. dalam melakukan promosi kesehatan khususnya promosi pada ibu hamil lebih menekankan pada perubahan-perubahan yang terjadi pada ibu hamil khususnya promosi anemia ibu hamil dan cara meminum tablet zat besi salah satunya dengan sosialisasi pentingnya konsumsi tablet zat besi yang tepat, makan makanan yang mengandung sumber zat 
besi, dan pentingnya vitamin $\mathrm{C}$ untuk meningkatkan penyerapan tablet zat besi di dalam tubuh.

4. Bagi Responden. Rutin memeriksakan kehamilan dan cek kadar Hb darah minimal sebulan sekali datang kepusat pelayanan kesehatan selama proses kehamilannya serta meningkatkan konsumsi tablet Fe dan asam folat selama kehamilan supaya terhindar dari kondisi penyakit anemia. 


\section{DAFTAR PUSTAKA}

Alimul, H. (2010). Riset Keperawatan dan Teknik Penulisan Ilmiah. Jakarta: Salemba Medika

Amirudin. (2007). Faktor Resiko Kejadian Anemia pada Ibu Hamil. Makasar: FKM UH Arikunto, S. (2009). Prosedur Penelitian. Jakarta: Rineka Cipta

Arisman. (2010) Gizi Daur Kehidupan. Jakarta: ECG . (2007). Buku Ajar Maternal Neonatal. Jakarta: YBP-SP

Chaaeril, A. R., Hidayat, A. (2017). Hubungan Pola Makan dengan Kejadian Anemia pada Ibu Hamil Trimester III di Puskesmas Jetis Kota Yogyakarta. Naskah Publikasi

Depkes RI. (2010). Panduan Makan Untuk Hidup Sehat. Jakarta: Depkes RI

Dinkes Kota Bengkulu. (2017). Profil Dinkes Kota Bengkulu. Bengkulu: Dinkes Kota Bengkulu

Irianto, K. (2012). Anatomi dan Fisiologi. Bandung: Alfabeta

Istiarti, M. (2012). Menanti Buah Hati. Yogyakarta: Media Persindo

Kasdu, D. (2008). Gizi Ibu Hamil Agar Bayi Cerdas. Jakarta: Bina Citra

Keisnawati., Yanti, D. A. M., Sulistianingsih, A. (2015). Faktor-Faktor Terjadinya Anemia pada Ibu Primigravida di Wilayah Kerja Puskesmas Tahun 2015. STIKES Peringsewu Lampung

Kementrian Kesehatan RI. (2015). Buku Ajar Kesehatan Ibu dan Anak. Jakarta: Pusat Pendidikan dan Pelatihan Tenaga Kesehatan

Kristiyanasari, W. (2010). Gizi Ibu Hamil. Yogyakarta: Nuha Medika

Lalage. (2013). Menghadapi Kehamilan Beresiko Tinggi. Yogyakarta: Abata Pess

Sandrayayuk, M, Benny, W, Jolie S. (2013). Hubungan Status Gizi dengan Kejadian Anemia pada Ibu Hamil di Wilayah Kerja Puskesmas Tuminting Kec. Tuminting Kota Manado. Ejournal Keperawatan

Manuaba, IBG. (2010). Ilmu Kesehatan, Penyakit Kandungan dan Keluarga Berencana. Jakarta: EGC . (2010). Gizi dalam Daur Kehidupan. Jakarta: EGC . (2010). Pengantar Kuliah Obstetri. Jakarta : EGC

Manuaba, I.B.G. (2015). Ilmu Kebidanan, Penyakit Kandungan dan Keluarga Berencana untuk Pendidikan Bidan. Jakarta: EGC

Manoe, M. (2010). Anemia dalam Kehamilan, Residen Divisi Fetomaternal Bagian Obstetri dan Ginekologi. Makasar: Fakultas Kedokteran Universitas Hasanuddin. (diakses tanggal 13 Oktober 2017), diunduh dari http://med.unhas.ac.id/obgin)

Notoatmodjo, S. (2010). Metodologi Penelitian. Jakarta: Rineka Cipta

Noverstiti, E. (2012). Faktor-Faktor yang Berhubungan dengan Kejadian Anemia pada Ibu Hamil Trimester III di Wilayah Kerja Puskesmas Air Dingin Kota Padang tahun 2012. STIKES Peringsewu Lampung

Nugraheny, E. (2009). Asuhan Kebidanan Pathologi. Yogyakarta: Pustaka Rihama

Prasetyono. (2009). Mengenal Menu Sehat Ibu Hamil. Jogjakarta: Diva Press

Price, SA. (2006). Patofisiologi. Jakarta: EGC

Proverawati, Asfuah, T. (2013). Anemia dan Anemia Kehamilan. Yogyakarta: Nuha Medika

Puskesmas Sawah Lebar (2015). Profil Kesehatan Puskesmas Sawah Lebar. UPT Puskesmas Sawah Lebar: Bengkulu

Proverawati, A. (2011). Anemia dan Anemia Kehamilan. Yogyakarta: Nuha Medika 
Riyanto, A. (2009). Pengolahan dan Analisis Data Kesehatan. Yogyakarta: Nuha Medika

Salmah. (2006). Asuhan Kebidanan Antenatal. Jakarta: EGC

Sarwono. (2008). Pelayanan Kesehatan Maternal dan Neonatal. Jakarta: Yayasan Bina Pustaka . (2008). Ilmu Kebidanan. Jakarta: Yayasan Bina Pustaka

Sayogo, S. (2007). Gizi Ibu Hamil. Jakarta: FK UI

Santoso, S. (2008). Kesehatan dan Gizi. Jakarta: Bina Citra

Setyawati, B., Syauqy, A. (2013). Perbedaan Asupan Protein, Zat Besi, Asam Folat, dan Vitamin B12 antara Ibu Hamil Trimester III Anemia dan Tidak Anemia di Puskesmas Tanggungharjo Kabupaten Grobogan. Journal of Nutrition College, 3(1), 228-234. http://ejournal-s1.undip.ac.id/index.php/jnc. diakses tanggal 12 Juni 2017

Sulistyawati, (2011). Asuhan Kebidanan Pada Ibu Hamil. Jakarta: EGC

Sulistyoningsih, H. (2011). Gizi untuk Kesehatan Ibu dan Anak. Jogjakarta: Graha Ilmu Soebroto I. (2010). Cara Mudah Mengatasi Problem Anemia. Jogjakarta: Bangkit Waryana. (2010). Gizi Reproduksi. Yogyakarta: Pustaka Rihana

WHO. (2012). Kematian Ibu dan Anak. (diakses tanggal 12 Oktober 2016), diunduh dari URL: http://puskesmas-oke

Zulaikha, E., Hani, U. (2015). Hubungan Pola Makan dengan Kejadian Anemia pada Ibu Hamil Trimester III di Puskesmas Pleret Bantul Tahun 2015. Naskah Publikasi 